\title{
The Development and Neurobiology of Infant Attachment and Fear
}

\author{
Margo S. Landers Regina M. Sullivan \\ Emotional Brain Institute, Nathan Kline Institute, Orangeburg, N.Y., and Child and Adolescent Psychiatry, \\ New York University School of Medicine, New York, N.Y., USA
}

\section{Key Words}

Social behavior $\cdot$ Mother-infant interactions - Olfactory bulb $\cdot$ Norepinephrine $\cdot$ Attachment $\cdot$ Imprinting $\cdot$ Locus coeruleus $\cdot$ Amygdala $\cdot$ Learning $\cdot$ Classical conditioning • Corticosterone $\cdot$ Stress

\begin{abstract}
Survival of altricial infants depends on attachment to the caregiver - a process that requires infants to identify, learn, remember, and approach their attachment figure. Here we review the neurobiology of attachment in infant rats where learning about the caregiver is supported by a specialized attachment neural circuitry to promote the infant-caregiver relationship. Specifically, the attachment circuit relies on infants acquiring learned preferences to the maternal odor, and this behavior is supported by the hyperfunctioning locus coeruleus and generous amounts of norepinephrine to produce experience-induced changes in the olfactory bulb and anterior piriform cortex. Infants also possess a reduced ability to acquire learned aversions or fear, and this behavior is facilitated through attenuated amygdala plasticity to block fear learning. Presumably, this attachment circuitry constrains the infant animal to express only learned preferences regardless of the quality of care received. As pups mature,
\end{abstract}

and begin to travel in and out of the nest, the specialized attachment learning becomes contextually confined to when pups are with the mother. Thus, when outside the nest, these older pups show learning more typical of adult learning, presumably to prepare for independent life outside the nest. The quality of attachment can alter this circuitry, with early life stress prematurely terminating the pups' access to the attachment system through premature functional activation of the amygdala. Overall, the attachment circuit appears to have a dual function: to keep pups close to the caregiver but also to shape pups' behavior to match the environment and define long-term emotion and cognition.

Copyright $\odot 2012$ S. Karger AG, Basel

\section{Introduction}

Hidden within the observable interactions of parent and offspring are sensorimotor, thermal, and nutrient-based events which have unexpected and widespread regulatory effects on infant behavior and physiology. These regulatory processes also appear to mediate long-term shaping effects exerted by early relationships [Hofer, 1994].

Attachment, the enduring bond between individual animals or humans [1], has a wide phylogenetic represen-

\section{KARGER \\ Fax +4161306 1234 \\ E-Mail karger@karger.ch}

www.karger.com
(C) 2012 S. Karger AG, Basel

0378-5866/12/0343-0101\$38.00/0

Accessible online at:

www.karger.com/dne
Regina Sullivan, $\mathrm{PhD}$

Child Study Center, New York University

16th floor, 215 Lexington Ave, New York, NY 10016 (USA)

Tel. +1 8453985511

E-Mail regina.sullivan@nyumc.org 
tation. Attachment also occurs throughout the life span and includes the mother attaching to her offspring, the offspring attaching to the caregiver, and mates attaching to one another. Considerable work has begun to document how the human brain forms attachment, with focus primarily limited to adult pair bonding and romantic love [2-9]. In other species, attachment research has focused on both infant and adults, with decades of research characterizing its neural basis at molecular, cellular, and systems levels [10-16]. In this review, we focus on infant attachment and integrate neurobiological attachment research in infant mammalian species.

Human infants exhibit attachment behaviors to their caregiver within minutes of birth. This occurs despite the birth process and transitioning from the familiar rhythmic and warm intrauterine environment to a world filled with new sensory experiences. This appears to be a daunting process since infants are required to identify their caregiver, form a memory about the experience with the caregiver, and continuously seek closeness to their caregiver for survival. Indeed, it seems that evolution has shaped the infant's social and emotional behavior to learn about and maintain proximity to the caregiver through this attachment process. The caregiver becomes the target for social behaviors and proximity-seeking behaviors and provides the food, protection, and warmth necessary for survival. Preprogrammed behaviors that are practiced in utero together with prenatal learning of the caregiver's smells and sounds greatly facilitate this transition and attachment. This is combined with the infant's exceptional postnatal learning, where other features of the mother and other caregivers are rapidly learned. For instance, within hours of birth, newborns orient towards and prefer their mother's voice, which is due to both prenatal and postnatal experience with the mother's voice [17]. Similar prenatal and postnatal experience seems to underlie newborns' response to maternal odor. Indeed, at birth, an infant placed on the mother's ventrum will crawl to a breast scented with amniotic fluid in preference to the untreated breast [18]. Importantly, maternal diet, which scents the amniotic fluid, directly influences this preferential response [19-21]. This odor also influences the infant's response to the mother, as expressed by orienting to the odor source and the odor's ability to attenuate crying $[21,22]$. Together, these studies illustrate that complex attachment behaviors of human attachment and bonding can be analyzed at the sensory system level to provide insight into how sensory stimuli can regulate behavior and physiology $[23,24]$.
Due to the limitation in the assessment of the neurobiology of attachment in humans, most of our understanding of the neurobiology of early life learning is based on animal research. Similar to humans, this survival-dependent learning is realized by exceptional learning processes early in life in other animal species. Early life attachment learning known as 'imprinting' is temporally limited to a window of time as first demonstrated following hatching in chicks $[23,25-30]$. The rapid learning and some of its neural support has been identified in mammals $[12,13]$. Importantly, while this animal work provides understanding and insights into human attachment, children show far more flexibility in forming attachment, including attachment to multiple caregivers throughout development [30] with continual learning occurring during awake and sleep [31].

Here, we will review the literature on the neurobiology of rodent infant attachment learning and how it is reorganized during development to presumably meet the changing needs of the infant as it transitions to independence. Such developmental transitions in behavior include a complex interplay between experience, learning, and neural changes and are thought to represent periods of vulnerability [32-35], although this process becomes the foundation for normal brain and behavior [36-39].

\section{Rodent Attachment Learning}

Attachment learning has been identified across many species, including rats [40-45], rabbits [46-49], mice [5052], and nonhuman primates [53-56]. During this time of dependency upon the mother, the infants' behaviors are focused on keeping physical contact with the mother. The sensory stimuli controlling this attachment vary with each species, but in the infant rat, this behavior is guided and controlled by maternal odor [57, 58]. Specifically, maternal odor controls infants' approach responses to the mother. Once pups make contact with the mother's ventrum, perioral somatosensory cues combined with maternal odor become the proximal maternal stimuli essential for nipple attachment $[59,60]$.

Infant rat pups, born blind and deaf, orient toward their mother's odor naturally within the nest, and decades of research have now shown that the maternal odor is not a pheromone, as originally proposed, but is learned [57-70]. The maternal odor elicits approach, physical contact with the mother, and nipple attachment, and without the maternal odor, pups show greatly diminished contact with the mother, failure to nipple attach, and ex- 
hibit low survival rates $[71,72]$. This has been demonstrated in naturalistic paradigms with the specific sensory qualities of the attachment figure (scent, texture, color, sound) during infant-caregiver interaction $[15,26$, $43,44,52]$. Any neutral odor can become the maternal odor simply by placing a novel odor (i.e. peppermint or citral) on the mother during mother-infant interactions or in the amniotic fluid during the last days of gestation $[41,57,65,73-76]$, although sensitive-period olfactory learning also occurs in controlled classical conditioning experiments performed outside the nest without the mother [64, 77-84]. Indeed, pairing a novel odor with a reward is sufficient to produce both learned odor preferences (demonstrated by an approach to the odor) and nipple attachment. However, perhaps the most striking feature of this early learning is the variety of stimuli that have been shown to function as a reward for young pups. Indeed, pairing a novel odor with milk, warmth, nursing, and tactile stimulation or stroking to mimic grooming all support odor learning $[41,63,64,70,73,76,82-88]$. As will be discussed below, painful stimuli can also support this odor attachment learning. Finally, the maternal odor continues to be learned repetitively throughout the early postnatal period, presumably to accommodate the changes induced in the maternal odor by the mother's diet.

Somatosensory input is a component of early approach behaviors in rat pups and supports early learning. Manipulations of somatosensory input from the first day of life throughout development have been done to examine the role of early somatosensory inputs, specifically involving the perioral area and whiskers, in infant attachment behavior. For example, sectioning of the infraorbital nerve, the sensory nerve that innervates the whiskers, was found to result in increased infant mortality due to the inability of pups to nipple attach normally, by disrupting nipple searching behaviors such as sweeping the snout over the ventrum just prior to grasping the nipple [89]. Furthermore, dewhiskering throughout development, which affects tactile learning and whisker behavior in adulthood [90], delays pups' nipple attachment in early life [91]. The importance of perioral somatosensory information to pups is also evident in pups' earlylife somatosensory learning. Specifically, passive whisker stimulation paired with reward results in stimulationevoked head and oromotor activity in pups as early as 1 day old, which is similar to the behavioral activation required for nipple attachment [92]. The most dramatic effects of early-life whisker deafferentation occur when whiskers begin to move (whisking) at postnatal day (PN) 12 just prior to eye and ear opening. Specifically, up- on examination of early exploratory behaviors, studies showed that deafferentation of the infant whiskers results in abnormal head turns, as well as disrupted latencies to explore and contact novel objects using the whiskers - although pups increase the use of paws and mouth to explore objects - and delayed whisking emergence and development $[93,94]$.

Together, this research indicates that the maternal odor is used for early attachment but is experienced among an array of sensory stimuli in the nest. Learning within any sensory system is likely a continuous and reciprocal process as pups mature and maternal behavior decreases. That is, as we place these behavioral learning results into the natural environment of pups, it is important to consider the myriad of sensory stimuli that are activated as pups interact with the mother and that learning likely co-occurs in all sensory systems. Specifically, as pups experience the maternal odor, it is accompanied by touch and warmth (somatosensory system) and the taste of milk (gustatory system), which are likely combined by pups as the maternal representation. These maternal stimuli each have a role in facilitating interactions with the mother: the odor orients pups to the mother, but at the nipple it is a combined signal of maternal odor plus stimulation of the perioral area (snout, whiskers) induced by pup's own motor responses (lateral head movements along the ventrum) that permit nipple location and grasping for nursing. Moreover, pups are likely to be simultaneously learning about the mother, siblings, and nest. Passive stimulation of the whiskers, for instance, may be a sensory cue that is used within the context of the nest while the pup is huddling with siblings or competing for access to a nipple.

\section{Neurobiology of Infant Attachment}

As illustrated in figure 1, this robust olfactory-based attachment learning system in rats is supported by a unique learning neural circuitry: infants' noradrenergic locus coeruleus (LC) and its abundant release of norepinephrine (NE) into the olfactory bulb induces the plasticity required for learning. Indeed, neural plasticity within the olfactory bulb is the critical site for physiological and anatomical changes within the brain to support the maternal odor learning [95-107]. Learning-induced plasticity has been well documented in naturalistic learning experiments $[24,80]$, and in conditioning experiments conducted outside the nest $[79,80,97-107]$. The maternal odor, whether natural or artificial (placed on the mother 


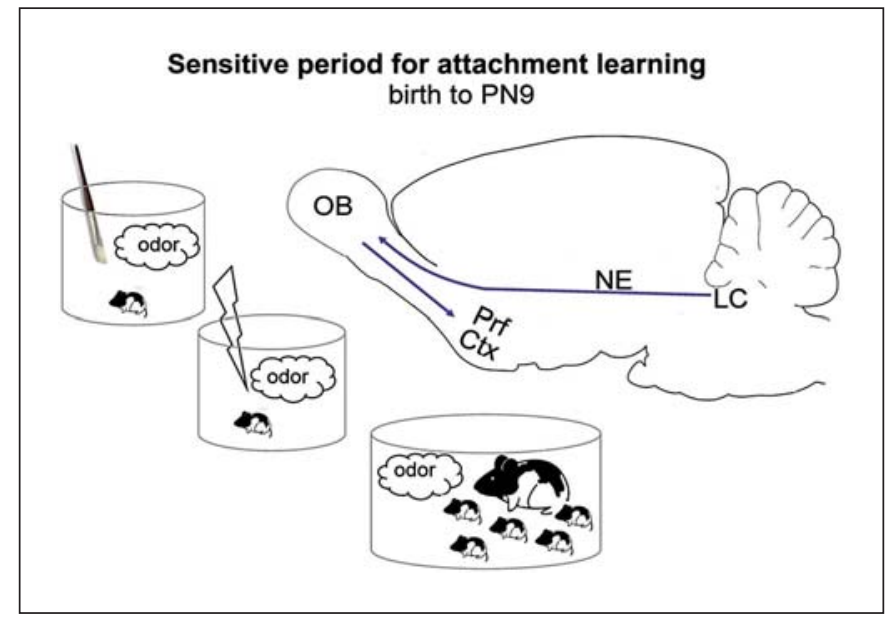

Fig. 1. Young infant rat pups very rapidly learn a new maternal odor. This learning is supported by a wide range of stimuli functioning as a reward that when paired with an odor results in the acquisition of a new maternal odor. For example, a novel odor paired with either tactile stimulation (mimics maternal licking), a mildly painful 0.5-mA shock/tail pinch (mimic mother stepping on pups/handling them roughly), or maternal care produces a new maternal odor. This learning is supported by a simplistic neural circuit (blue arrows) that requires the pairing of the novel odor with increased locus coeruleus (LC) norepinephrine (NE) release into the olfactory bulb $(\mathrm{OB})$. Learning-induced changes are found in the OB and anterior piriform cortex (Prf Ctx). At around $\mathrm{PN} 10$, functional emergence of the LC recurrent collaterals stimulate $\alpha_{2}$-postsynaptic receptors, which terminate LC firing and provide insufficient levels of $\mathrm{NE}$ to the $\mathrm{OB}$ to support the plasticity required for learning the new maternal odor [64, 65, 79-81, 85, 100-118, 148]. For colors, see online version.

or ingested), as well as odors learned through controlled classical conditioning studies all produce a similar enhancement of olfactory bulb neural responding. Neural assessments of these learning-induced olfactory bulb responses have been done using a variety of techniques including 2-deoxyglucose uptake, c-Fos immunohistochemistry, electrophysiology, CREB phosphorylation, and optical imaging, and the learning effects observed with these techniques are all confined to early life [97, 100-103, 106, 107].

$\mathrm{NE}$ appears to be both necessary and sufficient for the learning-induced behavioral and neural changes seen in pups. Olfactory bulb learning-induced changes are dependent upon NE released from the LC [108-118]. NE appears to evoke olfactory bulb plasticity by preventing the olfactory bulb's primary output neurons (mitral cells) from habituating to repeated olfactory stimulation [100]. At the molecular level, NE increases CREB phosphoryla- tion via cyclic AMP stimulation that likely underlies transcription of immediate/early- and late-response genes involved in synapse formation, neurogenesis, and learning [110]. Thus far, it seems that rat pups use the same intracellular cascades as observed in adult learning and memory [119-123].

One unique feature of infant learning is that the infant LC releases substantially more NE into the olfactory bulb during the sensitive period than during adulthood [118]. This appears due to pups' lack of the recurrent collateral inhibition from $\alpha_{2}$ inhibitory autoreceptors, which in adults and older pups inhibits LC firing and NE release into the olfactory bulb [124-127]. The LC $\alpha_{2}$ receptors' autoinhibition becomes functional around 10 days of age $[123,127]$, which changes the LC's stimulus-induced responding and greatly reduces the amount of NE release. Indeed, the functional emergence of the LC's $\alpha_{2}$ inhibitory autoreceptors signals the end of the pups' sensitive period of heightened ability to learn odors. At this point, NE begins to play a more modulatory role (vs. the necessary and sufficient role), which has been repeatedly demonstrated in adult learning $[128,129]$.

Thus far, we have discussed the experience-induced changes in the olfactory bulb and LC that are responsible for early-life learned odor associations. While cellular and physiological changes in the olfactory bulb play a prominent role in the early learning process, the piriform cortex (part of the olfactory cortex) appears to have an important role in assigning the hedonic value to a learned odor. Primary sensory axons of mitral cells of the olfactory bulb directly project to the piriform cortex $[130,131]$. The piriform cortex can be divided, both anatomically and physiologically, into two distinct structures: (1) the anterior piriform cortex, which is influenced by direct olfactory bulb input, and (2) the posterior piriform cortex, which is more influenced by input from limbic structures and intracortical connections [132-134]. Early-life learned odor preferences engage the anterior piriform cortex (with no detectable activity in the posterior piriform), while learned odor aversions in older pups and adults support posterior piriform cortical activity [80].

Since naturalistic early attachment learning likely produces simultaneous learning in multiple sensory systems, we also questioned whether the NE was important for pup learning within the somatosensory system. Indeed, the noradrenergic LC innervates the somatosensory system along the ascending somatosensory pathway [135]. We found that NE is necessary and sufficient to induce somatosensory learning during the first days of life. Specifically, newborn rat pups can be conditioned to 
whisker stimulation paired with increased systemic NE [135]. We were unable to detect learning-associated changes in the immature barrel cortex $[91,92]$. Thus, NE is implicated in plasticity within the whisker system in adulthood [136] and during development [137] and complements the role of NE in the olfactory system discussed above. This suggests that NE-associated early classical conditioning may represent a common principle across sensory system development.

\section{Neurobiology of Pain-Associated Attachment}

Another unusual feature of pup attachment learning is that it persists regardless of the quality of care that is received. That is, pups with an abusive mother also form a strong attachment $[24,80]$. This pain-related attachment could be mimicked outside the nest, where pups can learn a new maternal odor, even when that odor is paired with a $0.5-\mathrm{mA}$ shock or tail pinch $[69,70]$. This paradoxical attachment learning suggests that there is suppression of avoidance and fear learning, perhaps to protect pups from learning to fear the mother. Since the conceptualization of attachment theory, the attenuation of fear and avoidance is known to be a critically important characteristic of human attachment learning [1, 23-24]. In other species, imprinting studies demonstrated that shocking young chicks in the presence of the surrogate caregiver elicits an approach response to the caregiver rather than an aversion [27-28]. Abusive caregiving also elicits attachment in nonhuman primates [138-141].

The ability of young pups to learn an attachment to an abusive caregiver is likely related to the suppression of learning systems that would enable pups to fear or avoid their caregiver. For example, fear of predators, cued fear conditioning, inhibitory conditioning, and passive avoidance do not functionally emerge until after the sensitive period has terminated at PN10 [69, 77-80, 142-154]. Indeed, the fear-conditioning paradigm of odor-shock (0.5$\mathrm{mA}$ shock) conditioning produces a paradoxical odor preference in young rat pups (less than 10 days of age, i.e. sensitive period) despite an apparent pain response [45, 147-151]. The same paradigm produces an odor aversion in pups older than PN10 signaling the end of the sensitive period for attachment learning and the emergence of adult-like fear learning $[45,69,79,148]$.

Evidence suggests that the absence of amygdala plasticity is responsible for the paradoxical response to aversive stimuli during the sensitive period $[15,45,79,148$, $153,154]$. In adult animals, the amygdala is the brain area responsible for fear learning in both conditioning and natural fear paradigms [155-168]. In contrast, the amygdala does not exhibit learning-associated plasticity during laboratory or natural fear paradigms in infant rat pups at less than PN10 $[79,80,153,169,170]$. In these sensitive-period pups, odor-shock $(0.5 \mathrm{~mA})$ conditioning supporting odor preference learning is unaltered by pharmacological suppression of the amygdala and initially suggested to us that the amygdala may simply be too immature to support fear learning. Indeed, peak neurogenesis in the amygdala begins in the first week of life, yet the functional development of the amygdala extends into adolescence [171-179]. Synaptic development begins at around PN5, with a protracted increase between PN10 and 20, and an adult-like synaptic profile is not reached until early adolescence [163, 171]. Long-term synaptic plasticity induced in the adult basolateral amygdala does not emerge until the end of the attachment learning sensitive period [180].

Thus, infant odor-shock conditioning activates the same brain circuitry as appetitive learning paradigms using milk, warmth, or stroke (olfactory bulb, anterior piriform cortex, LC), and requires the absence of amygdala plasticity, unlike in the adult. These data suggest that instead of being an immature adult prototype, the unique infant learning circuitry has been conserved by evolution to support attachment to the caregiver. Many animals including humans form attachments to abusive caregivers, presumably to enhance survival [181, 182].

It is important to mention that infants can learn aversions under some circumstances. Specifically, infant rats are able to learn to avoid odors if paired with malaise, such as that produced by a lithium chloride injection or $1.0-\mathrm{mA}$ shock [183-204]. Interestingly, while in adult and preweaning rats the amygdala responds to odor-malaise conditioning [205], in infants, odor-malaise uses a nonamygdala neural circuit for odor aversion learning [200, 201]. Another remarkable constraint exists on aversion learning during infancy: if neonatal rats are nursing during odor/taste-lithium chloride conditioning, this produces a learned odor preference or blocks taste learning [200, 201, 206-208].

In summary, data indicate that infants do not readily learn aversions, and we attribute this to unique neural circuitry optimized to facilitate attachment to the caregiver. In figure 1, we illustrate our current understanding of this early social attachment circuit. Next, we review how this circuitry changes to transition the developing animal from attachment learning to learning that can accommodate both learned preferences and aversions. In- 
deed, as will be discussed in the next sections, the sensitive period can be altered to support fear learning simply by elevating corticosterone (CORT), and older pups can have their sensitive period learning reinstated by lowering CORT, which can be done naturalistically dependent upon the mother's presence or absence.

\section{CORT Controls the Age Limits for the Sensitive Period for Attachment Learning}

The emergence of fear learning signals the end of the attachment-sensitive period and coincides with delayed stress-induced CORT release in infants. Before we describe the role of CORT in pup attachment learning, some unique features of their stress system will be described. Early in the rat pups' life, CORT basal levels are relatively low and most stressors do not induce CORT release, a development period known as the stress hyporesponsive period [209-218]. Maternal sensory stimulation during nursing or grooming maintains pups' low CORT levels [39, 219-222]. In fact, maternal separation (greater than a few hours) deprives the pup of the regulating sensory stimuli from the mother and increases CORT levels, while return of maternal stimulation is able to return pups' CORT to normal low levels. As the pups' stress hyporesponsive period ends at around PN10, stressful stimuli increase pups' CORT levels, although the presence of the mother can greatly attenuate CORT levels. This attenuation of CORT levels by maternal presence is referred to as 'social buffering' and occurs in many different animal species, as well as humans [52-56, 221, 222]. This reduced stress reactivity is hypothesized to protect the developing organism from the negative effects of stress hormones [223-229]. Indeed, high levels of CORT administered to the neonatal rat affect growth, brain size, neuroendocrine function, and cellular structure and formation.

CORT plays a modulatory role in adult fear and avoidance conditioning by increasing or decreasing learning strength $[229,230]$. However, CORT has a direct impact on infant conditioning by switching whether infants will learn avoidance or attachment. Specifically, increasing CORT by systemic injections or by intra-amygdala infusions in pups during either fear conditioning or presentation of a predator odor is sufficient to produce an amygdala-dependent fear response, further indicating that pain threshold is not a variable in pups' emergence of fear learning [45, 72, 147-149, 151, 153, 231]. At PN10, pups have a sufficient endogenous level of stress-induced

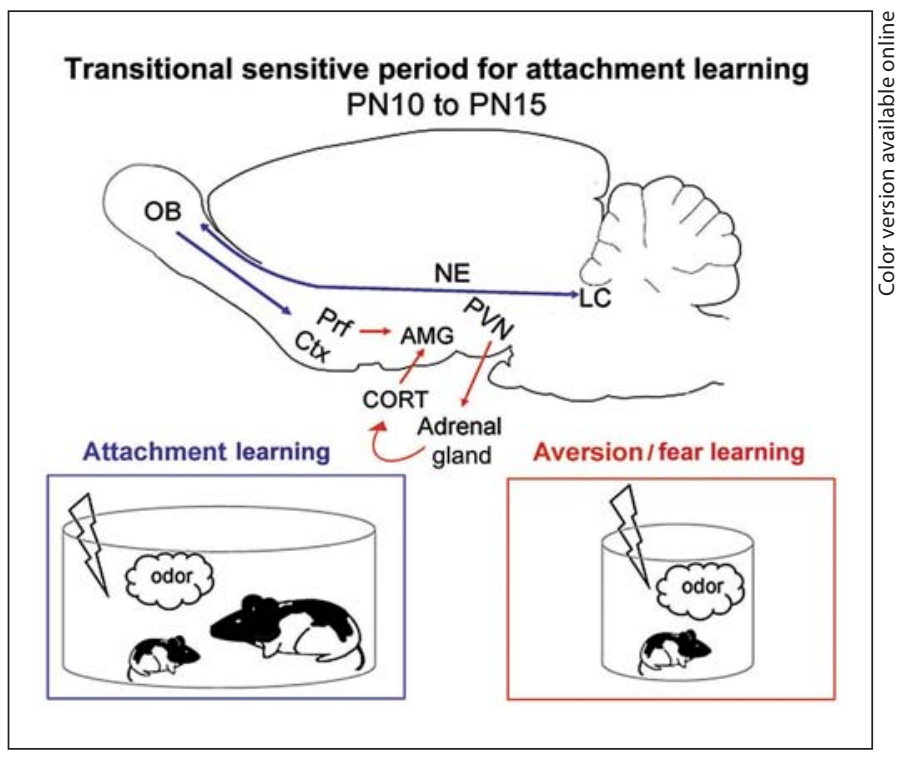

Fig. 2. As pups mature and begin to make brief trips outside the nest, attachment learning only occurs if the mother is present. Pups appear to use the same attachment learning circuitry used during the sensitive period when with the mother. Away from the mother, the more adult-like amygdala-dependent (AMG) fear learning system emerges. Pups' ability to switch between these two learning systems is due to emerging systems: (1) shock begins to induce increased release of the stress hormone CORT at around PN10, which supports aversion/fear learning and (2) maternal presence blocks this shock-induced CORT release, which prevents amygdala plasticity and reinstates the attachment learning. Maternal presence (anesthetized) blocks adrenal gland CORT release by blocking NE into the PVN. By 16 days old, maternal presence does not block amygdala-dependent fear learning. The attachment neural circuitry is illustrated in blue and the aversion/fear learning circuitry is illustrated in red $[15,24,45,79,137,148,169$, $153,180,200,201]$. For colors, see online version.

CORT to permit amygdala plasticity and fear. In these older pups (PN10-15), reducing CORT levels through social buffering (maternal presence) or intra-amygdala receptor CORT blocker prevents fear learning and reinstates attachment learning through prevention of the participation of the amygdala in learning $[105,148,200]$. Since this effect of maternal presence lowering CORT to prevent fear learning is only possible through PN15, this limit defines a transitional sensitive period that follows the sensitive period for attachment learning [105]. Thus, the age range for an increase in CORT to terminate attachment learning in the infant rat pup is $6-15$ days of age [105]. We suggest that this age limit protects pups from learning an aversion to the maternal odor while pups are dependent on maternal care and ends after weaning when 
survival outside the nest is possible. We also suggest that 5-day-old pups and younger do not have an amygdala sufficiently mature to support avoidance learning [171179].

As illustrated in figure 2, the mechanism for the mother's presence (social buffering) to change pup learning appears to be at the level of the hypothalamic paraventricular nucleus (PVN), a brain area critical for initiating the action of the hypothalamic-pituitary-adrenal axis. Specifically, the PVN appears to coordinate the diverse neural input from different types of stressors. While the PVN receives input from different neurotransmitters, from different brain areas, NE is a major player in controlling this brain area $[232,233]$. Social buffering, at least in rats, results in attenuation of PVN neural activity and suppression of PVN NE release. This was demonstrated in pups during the transitional sensitiveperiod age (PN12-14) where suppression of PVN NE release blocked CORT to promote attachment learning even during fear conditioning [45]. Additionally, microinfusions of NE into the PVN initiates fear learning even in the presence of the mother [45]. In an adult rat during stress, the main source of NE in the PVN is derived from ascending brainstem pathways (A1, A2, with smaller amounts from the LC); however, we do not yet have this information in infant rat pups. Together these data represent a transitional period of pups' continued dependence upon maternal presence inside the nest, while enabling fear as an adaptive mechanism to transition to life outside the nest.

The relationship between the mother and pup is reciprocal and the pups can also influence the mother's CORT level, although in the opposite direction [234-236]. That is, the mother has a robust stress response with the pups and a stress hyporesponsive state while away from her pups. The ability of social stimuli to control CORT is similar in both the mother and infant via modulation of NE in the PVN. The robust stress response mounted by the mother presumably enables the mother to protect her pups, such as occurs with maternal aggression.

To summarize, during the early attachment period or in older pups with maternal presence, pups do not mount a CORT response to pain (i.e., shock), which prevents amygdala plasticity, and ultimately prevents the pups from learning fear. The ability of CORT levels to turn on and off the pups' fear system may inhibit fear when in the nest, but permit fear when pups are old enough to explore outside the nest. Indeed, crawling transitions to walking just at the age pups begin to mount a CORT response (PN10).

Infant Attachment and Fear

\section{Long-Term Consequences of Early-Life Environment}

Learning during early life is important to subsequent behavior in the adult rat. For example, the learned maternal odor leaves a lasting trace throughout the life span, although the role of the conditioned odor in modifying behavior changes from that used during infancy (attachment to the mother) to that used during adulthood (adult mate preference and parenting) $[95,237,238]$. Furthermore, recent work from our lab suggests that similar enduring, depressive-like effects and social behavior deficits are produced by repeated odor-shock conditioning and by rearing pups with a maltreating mother, although these effects are most pronounced after weaning [24, 72, 237]. The conditioned odors (the odor used in odor-shock conditioning) also evoke enhanced neural responses in the olfactory bulb and attenuated amygdala activation in the adult, which are aspects of pups' unique neural response to the maternal odor $[237,238]$.

This early-life learning complements the more general effects of the early environment in the regulation of behavior throughout the life span, which has long been recognized in clinical and experimental studies [239251]. Indeed, sensory stimulation from the mother during development is a necessary component in shaping healthy adult cognition and emotion in rodents, nonhuman primates, and humans [36-40, 140, 141]. More recent studies, including our own, which involve manipulations of the early environment are providing a clear understanding of how early stress and trauma may have a lasting effect on adult behavior. For example, the maternal deprivation or maternal separation paradigm, which is a model of infant neglect, removes pups from the nest for an extended period of time (3-24 h) either once or multiple times during the first and second postnatal weeks. The maternal separation procedure - also viewed as deprivation of multiple sensory stimuli from the mother - has been shown to regulate pups' CORT, although it has ubiquitous effects. Rat pups' initial behavioral responses to maternal separation consist of increased behavioral activity and vocalizations, including ultrasonic vocalization and increased activity, which likely attract the mother [252-254]. The initial responses can be greatly attenuated if pups are provided with adequate warmth and a source of maternal odor. However, within a few hours of separation, the hypothalamic-pituitary-adrenal axis is engaged and CORT increases as a result of increases in adrenocorticotropic hormone that control the stress response at the level of the pituitary, although there are additional ubiquitous effects through-

Dev Neurosci 2012;34:101-114 
out the brain. This disruption in the hypothalamic-pituitary-adrenal axis and its immediate and enduring effects on the brain and behavior has clearly indicated the important role of stress hormones in organizing emotional and cognitive development, although there are likely multiple ways of altering normal brain development. Specifically, maternal separation affects gene expression, glucocorticoid receptors, neural function (i.e., long-term synaptic plasticity), and the long-term susceptibility to stress-related diseases [239-251]. Thus, research using naturalistic environmental stimuli has greatly expanded our understanding of the potential CORT-related mechanisms using different levels of analysis and has provided a stronger link between clinical and basic research.

\section{Clinical Implications of Early Attachment Learning}

The clinical literature suggests that the infant's relationship to the caregiver is important in shaping human behavior and the trajectory of brain development. The individual that experiences early abuse or neglect has a greater probability of psychopathological disorders, although access to at least one strong positive figure has been shown to dramatically decrease this risk [1,255]. For example, the Bucharest Early Intervention Project provides a long-term study on the effects of institutionalization on cognitive abilities and brain function in young children and the benefits of early intervention ( less than 2 years old). These studies have highlighted a sensitive period for attachment in early life and the unique window of opportunity to repair early-life effects of a deprived, harsh environment [255-260]. These results greatly enhance our understanding of clinical and basic research studies, although the effects of social deprivation and abuse within the attachment dyad and nonattachmentrelated trauma may have different clinical outcomes [261]. The long-term effects of these clinical studies have been highlighted with brain imaging research showing that these early adverse events are correlated with aberrant adult brain functioning, most notably in the limbic system, frontal cortex, and the cerebellum [262-271]. Although the neurobiological effects of abuse from the caregiver are still not well understood, especially with respect to neural circuitry, overall the clinical work suggests that both mental and physical health during childhood are affected with strong convergence of data across species and studies, and this pattern continues through adolescence into adulthood.
In this review, we have outlined some neural and behavioral properties of infant attachment that go beyond its support of proximity-seeking and attachment behaviors. These unique features suggest that the infant rat's attachment circuit is not simply due to the absence or immaturity of neural structures but rather to its unique characteristics, producing an infant brain that optimizes attachment to the caregiver. There is some evidence that an attachment circuit may exist in the child's brain, which was originally discussed by Bowlby [1], but this may be difficult to identify and test in children. Bowlby's original attachment theory was strongly based on a vast integration of clinical observations and pioneering research on mother-infant relations in animals and imprinting [25$27,138,272-274]$. It should be noted that the paradigm shifting work in the Bucharest Early Intervention Project [255-260] and its use of rigorous controls has provided evidence of a sensitive period for attachment ranging from the first to third year of life depending on the behavioral neural system being studied and the age measured. While the details of the neural circuitry and timing of attachment are still unclear in human children, the rat pup model system may provide a greater understanding of the neurobiology of attachment and secure a foundation for the exploration of unique qualities of neural structures during early life. Additionally, the rat pup model of attachment can be used to identify the critical role of social interactions in infancy for the ability to test normal processing of sensory stimuli and learning at the earliest moments of postnatal life.

\section{Acknowledgments}

This work was supported by grants NIH-DC009910, NIHMH091451, NSF-IOB0850527/0544406 to R.M.S. We would like to thank Sarah Graybill for her editing of an earlier version of the manuscript.
References
1 Bowlby J: Attachment. New York, Basic Books, 1965.
-2 Bartels A, Zeki S: The neural correlates of maternal and romantic love. Neuroimage 2004;21:1155-1166.
-3 Zeki S: The neurobiology of love. FEBS Lett 2007;581:2575-2579.
4 Lorberbaum JP, Newman JD, Horwitz AR, Dubno JR, Lydiard RB, Hamner MB, Boh- ning DE, George MS: A potential role for thalamocingulate circuitry in human mater- nal behavior. Biol Psychiatry 2002;51:431- 445. 
$\checkmark 5$ Ranote S, Elliott R, Abel KM, Mitchell R, 22 Sullivan RM, Toubas P: Clinical usefulness Deakin JF, Appleby L: The neural basis of maternal responsiveness to infants: an fMRI study. Neuroreport 2004;15:1825-1829.

6 Swain JE: Baby stimuli and the parent brain: functional neuroimaging of the neural substrates of parent-infant attachment. Psychiatry (Edgmont) 2008;5:28-36.

7 Swain JE, Lorberbaum JP, Kose S, Strathearn L: Brain basis of early parent-infant interactions: psychology, physiology, and in vivo functional neuroimaging studies. J Child Psychol Psychiatry 2007;48:262-287.

8 Noriuchi M, Kikuchi Y, Senoo A: The functional neuroanatomy of maternal love: mother's response to infant's attachment behaviors. Biol Psychiatry 2008;63:415-423.

$\checkmark 9$ Leuner B, Glasper ER, Gould E: Parenting and plasticity. Trends Neurosci 2010;33:465473.

10 Moffat SD, Suh EJ, Fleming AS: Noradrenergic involvement in the consolidation of maternal experience in postpartum rats. Physiol Behav 1993;53:805-811.

-11 Lévy F, Keller M. Olfactory mediation of maternal behavior in selected mammalian species. Behav Brain Res 2009;200:336-345.

12 Hofer MA, Sullivan RM: Toward a neurobiology of attachment; in Lucian CA (ed): Handbook of Developmental Cognitive Neuroscience. Cambridge, the MIT Press, 2008, pp 787-806.

13 Insel TR, Young LJ: The neurobiology of attachment. Nat Rev Neurosci 2001;2:129-136.

14 Romeo RD, Tang AC, Sullivan RM: Early life experiences: enduring behavioral and endocrinological consequences; in Pfaff D, Arnold A, Etgen AM (eds): Hormones, Brain and Behavior. Boston, Academic Press, 2002, pp 1414-1415.

-15 Barr G, Moriceau S, Shionoya K, Muzny K, Gao P, Sullivan RM: Transitions in infant learning are modulated by dopamine in the amygdala. Nat Neurosci 2009;12:1367-1369.

$\checkmark 16$ Broad KD, Curley JP, Keverne EB: Motherinfant bonding and the evolution of mammalian social relationships. Phil Trans R Soc Lond B Biol Sci 2006;361:2199-2214.

$\checkmark 17$ DeCasper AJ, Fifer WP: Of human bonding: newborns prefer their mothers' voices. Science 1980;208:1174-1176.

18 Varendi H, Porter RH, Winberg J: Attractiveness of amniotic fluid odor: evidence of prenatal olfactory learning? Acta Paediatr 1996;85:1223-1227.

$\checkmark 19$ Lecanuet JP, Schaal B: Fetal sensory competencies. Eur J Obstet Gynecol 1996;68:1-23.

-20 Schaal B, Marlier L, Soussignan R: Human foetuses learn odours from their pregnant mother's diet. Chem Senses 2000;25:729737.

21 Schaal B, Marlier L, Soussignan R: Responsiveness to the odour of amniotic fluid in the human neonate. Biol Neonate 1995;67:397406. of maternal odor in newborns: soothing and feeding preparatory responses. Biol Neonate 1998;74:402-408.

23 Hofer MA: Early relationships as regulators of infant physiology and behavior. Acta Paediatr 1994;83:9-18.

24 Raineki C, Moriceau S, Sullivan RM: Developing a neurobehavioral animal model of infant attachment to an abusive caregiver. Biol Psychiatry 2010;67:1137-1145.

25 Hess E: Ethology: An approach to the complete analysis of behavior; in Brown EG, Hess E, Mendler G (eds): New Directions in Psychology. New York, Holt, Rinehart and Winston, 1962, pp 159-199. bird's environment; in Lorenz K (ed): Studies in Animal and Human Behavior. Cambridge, Harvard University Press, 1970.

27 Salzen E: Imprinting and environmental learning; in Aronson DL, Rosenblatt J (eds): Development and Evolution of Behavior. San Francisco, WH Freeman, 1970.

28 Bolhuis JJ, Honey RC: Imprinting, learning and development: from behaviour to brain and back. Trends Neurosci 1998;21:306-311.

29 Gottlieb G: 'Imprinting' in nature. Science 1963;139:497-498.

30 Rosen KS, Burke PB: Multiple attachment relationships within families: mothers and fathers with two young children. Dev Psychol 1999;35:436-444.

31 Reeb-Sutherland BC, Fifer WP, Byrd DL, Hammock EA, Levitt P, Fox NA: Onemonth-old human infants learn about the social world while they sleep. Dev Sci 2011; 14:1134-1141.

32 Adriani WL, Laviola G: Windows of vulnerability to psychopathology and therapeutics strategy in the adolescent rodent model. Behav Pharmacol 2004;15:341-352.

33 Hensch TK: Critical period regulation. Ann Rev Neurosci 2004;27:549-579.

34 Crews F, He J, Hodge C: Adolescent cortical development: a critical period of vulnerability for addiction. Pharmacol Biochem Behav 2007;86:189-199.

35 Sullivan RM, Holman P: Transitions in sensitive period attachment learning in infancy: the role of corticosterone. Neurosci Biobehav Rev 2010;34:835-844.

36 Bell RW, Denenberg VH: The interrelationships of shock and critical periods in infancy as they affect adult learning and activity. Anim Behav 1962;11:21-27.

37 Denenberg VH: Early experience and emotional development. Sci Am 1963;208:138146.

38 Levine S: Comparative and psychobiological perspectives on development; in Collins WA (ed): Minnesota Symposia on Child Psychology. Hillsdale, Erlbaum, 1982, vol 15, pp 2953.
26 Lorenz K: Companions as factors in the
39 Levine S: Primary social relationships influence the development of the hypothalamicpituitary-adrenal axis in the rat. Physiol Behav 2001;73:255-260.

40 Alberts JR, May B: Nonnutritive, thermotactile induction of filial huddling in rat pups. Dev Psychobiol 1984;17:161-181.

41 Teicher MH, Flaum LE, Williams M, Eckhert SJ, Lumia AR: Survival, growth and suckling behavior of neonatally bulbectomized rats. Physiol Behav 1978;21:553-561.

42 Risser JM, Slotnick BM: Nipple attachment and survival in neonatal olfactory bulbectomized rats. Physiol Behav 1987;40:545-549.

43 Blass EM, Teicher MH: Suckling. Science 1980;210:15-22.

44 Polan HJ, Hofer MA: Olfactory preference for mother over home nest shavings by newborn rats. Dev Psychobiol 1998;33:5-20.

45 Shionoya K, Moriceau S, Bradstock P, Sullivan RM: Maternal attenuation of hypothalamic paraventricular nucleus norepinephrine switches avoidance learning to preference learning in preweanling rat pups. Horm Behav 2007;52:391-400.

46 Distel H, Hudson R: The contribution of the olfactory and tactile modalities to the nipple-search behaviour of newborn rabbits. J Comp Physiol 1985;157:599-605.

47 Hudson R: Do newborn rabbits learn the odor stimuli releasing nipple-search behavior? Dev Psychobiol 1985;18:575-585.

48 Hudson R, Distel H: Nipple location by newborn rabbits: behavioral evidence for pheromonal guidance. Behaviour 1983;85:260274.

49 Coureaud G, Schaal B, Coudert P, Rideaud P, Fortun-Lamothe L, Hudson R, Orgeur P: Immediate postnatal suckling in the rabbit: its influence on pup survival and growth. Reprod Nutr Devel 2000;40:19-32.

50 Moles A, Kieffer BL, D'Amato FR: Deficit in attachment behavior in mice lacking the mu-opioid receptor gene. Science 2004;304: 1983-1986.

51 Armstrong CM, DeVito LM, Cleland TA: One-trial associative odor learning in neonatal mice. Chem Senses 2006;31:343-349.

52 Hennessy MB, Li J, Levine S: Infant responsiveness to maternal cues in mice of 2 inbred lines. Dev Psychobiol 1980;13:77-84.

53 Hennessy MB, Kaiser S, Sachser N: Social buffering of the stress response: diversity, mechanisms, and functions. Front Neuroendocrinol 2009;30:470-482.

54 Carter CS, Keverne EB: Neurobiology of Social Affiliation and Pair Bonding. San Diego, Academic Press, 2002.

55 DeVries AC, Glasper ER, Detillion CE: Social modulation of stress responses. Physiol Behav 2003;79:399-407.

56 Kikusui T, Winslow JT, Mori Y: Social buffering: relief from stress and anxiety. Philos Trans R Soc Lond B Biol Sci 2006;361:22152228. 
57 Galef BG, Jr., Kaner HC: Establishment and maintenance of preference for natural and artificial olfactory stimuli in juvenile rats. J Comp Physiol Psychol 1980;94:588-595.

58 Leon M: The neurobiology of filial learning. Ann Rev Psychol 1992;43:377-398.

59 Teicher MH, Blass EM: First suckling response of the newborn albino rat: the roles of olfaction and amniotic fluid. Science 1977; 198:635-636.

60 Hofer MA, Shair H, Singh P: Evidence that maternal ventral skin substances promote suckling in infant rats. Physiol Behav 1976; 17:131-136.

61 Brunjes PC, Alberts JR: Olfactory stimulation induces filial preferences for huddling in rat pups. J Comp Physiol Psychol 1979;93: 548-555.

62 Miller JS, Jagielo JA, Spear NE: Age-related differences in short-term retention of separable elements of an odor aversion. Exp Psychol Anim Behav Process 1989;15:194-201.

63 Pedersen PE, Williams CL, Blass EM: Activation and odor conditioning of suckling behavior in 3-day-old albino rats. Exp Psychol Anim Behav Process 1982;8:329-341.

-64 Moriceau S, Shionoya K, Jakups K, Sullivan RM: Early life stress disrupts attachment learning: the role of amygdala corticosterone, locus coeruleus CRF and olfactory bulb NE. J Neurosci 2009;29:15745-15755.

-65 Sullivan RM, Wilson DA, Wong R, Correa A, Leon M: Modified behavioral and olfactory bulb responses to maternal odors in preweanling rats. Brain Res Dev Brain Res 1990; 53:243-247.

-66 Terry LM, Johanson IB: Effects of altered olfactory experiences on the development of infant rats' responses to odors. Dev Psychobiol 1996;29:353-377.

67 Campbell BA: Reflections on the ontogeny of learning and memory; in Kail R, Spear NE (ed): Comparative Perspectives on the Development of Memory. Hillsdale, Erlbaum Associates, 1984, pp 23-35.

68 Leon M: Dietary control of maternal pheromone in the lactating rat. Physiol Behav 1975; 14:311-319.

69 Rudy JW, Cheatle MD: Odor-aversion learning in neonatal rats. Science 1977;198:845846.

-70 Sullivan RM, Brake SC, Hofer MA, Williams CL: Huddling and independent feeding of neonatal rats can be facilitated by a conditioned change in behavioral state. Dev Psychobiol 1986;19:625-635.

-71 Singh PJ, Tobach E: Olfactory bulbectomy and nursing behavior in rat pups (Wistar DAB). Dev Psychobiol 1975;8:151-164.

-72 Moriceau S, Raineki C, Holman JD, Holman JG, Sullivan RM: Enduring neurobehavioral effects of early life trauma mediated through learning and corticosterone suppression. Front Behav Neurosci 2009:3:22.
Galef BG Jr, Sherry DF: Mother's milk: a medium for transmission of cues reflecting the flavor of mother's diet. J Comp Physiol Psychol 1973;83:374-378.

74 Caza PA, Spear NE: Short-term exposure to an odor increases its subsequent preference in preweanling rats: a descriptive profile of the phenomenon. Dev Psychobiol 1984;17: 407-422.

75 Duveau A, Godinot F: Influence of the odorization of the rearing environment on the development of odor-guided behavior in rat pups. Physiol Behav 1988;43:265-270.

76 Sevelinges Y, Lévy F, Mouly AM, Ferreira G: Rearing with artificially scented mothers attenuates conditioned odor aversion in adulthood but not its amygdala dependency. Behav Brain Res 2009;198:313-320.

77 Haroutunian V, Campbell BA: Emergence of interoceptive and exteroceptive control of behavior in rats. Science 1979;205:927-929.

78 Camp LL, Rudy JW: Changes in the categorization of appetitive and aversive events during postnatal development of the rat. Dev Psychobiol 1988;21:25-42.

79 Sullivan RM, Landers M, Yeaman B, Wilson DA: Good memories of bad events in infancy. Nature 2000;407:38-39.

80 Roth T, Sullivan R: Memory of early maltreatment: neonatal behavioral and neural correlates of maternal maltreatment within the context of classical conditioning. Biol Psychiatry 2005;57:823-831.

81 Sullivan RM, Stackenwalt G, Nasr F, Lemon C, Wilson DA: Association of an odor with activation of olfactory bulb noradrenergic Breceptors or locus coeruleus stimulation is sufficient to produce learned approach response to that odor in neonatal rats. Behav Neurosci 2000;114:957-962.

82 Brake SC: Suckling infant rats learn a preference for a novel olfactory stimulus paired with milk delivery. Science 1981;211:506508.

83 Johanson IB, Hall WG: Appetitive learning in 1-day-old rat pups. Science 1979;205:419421.

84 Johanson IB, Teicher MH: Classical conditioning of an odor preference in 3-day-old rats. Behav Neural Biol 1980;29:132-136.

85 McLean JH, Darby-King A, Sullivan RM, King SR: Serotonergic influence on olfactory learning in the neonate rat. Behav Neural Biol 1993;60:152-162.

86 Weldon DA, Travis ML, Kennedy DA: Posttraining D1 receptor blockade impairs odor conditioning in neonatal rats. Behav Neurosci 1991; 105:450-458.

87 Wilson DA, Sullivan RM: Neurobiology of associative learning in the neonate: early olfactory learning. Behav Neural Biol 1994;61: $1-18$.

88 Cheslock SJ, Varlinskaya EI, Petrov ES, Spear NE: Rapid and robust olfactory conditioning with milk before suckling experience: promotion of nipple attachment in the newborn rat. Behav Neurosci 2000;114:484-495.
89 Hofer MA, Fisher A, Shair H: Effects of in fraorbital nerve section on survival, growth, and suckling behaviors of developing rats. J Comp Physiol Psychol 1981;95: 123-133.

90 Carvell GE, Simons DJ: Abnormal tactile experience early in life disrupts active touch. J Neurosci 1996;16:2750-2757.

-91 Sullivan RM, Landers MS, Flemming J, Vaught C, Young TA, Polan JH: Characterizing the functional significance of the neonatal rat vibrissae prior to the onset of whisking. Somatosens Mot Res 2003;20: 157-162.

92 Landers MS, Sullivan RM: Vibrissae evoked behavior and conditioning before functional ontogeny of somatosensory vibrissae cortex. J Neurosci 1999;19:5131-5137.

93 Welker W: Analysis of sniffing of the albino rat. Behaviour 1964;12:223-244.

94 Landers MS, Zeigler HP: Development of rodent whisking: trigeminal input and central pattern generation. Somatosens Mot Res 2006;23:1-10.

$\$ 95$ Fillion T, Blass E: Infantile experience with suckling odors determines adult sexual behavior in male rats. Science 1986;231:729731.

96 Fleming AS, O’Day DH, Kraemer GW: Neurobiology of mother-infant interactions: experience and central nervous system plasticity across development and generations. Neurosci Biobehav Rev 1999;23: 673-685.

-97 Johnson BA, Woo CC, Duong H, Nguyen V, Leon M: A learned odor evokes an enhanced fos-like glomerular response in the olfactory bulb of young rats. Brain Res 1995;699:192-200.

$\checkmark 98$ Moore C, Jordan L, Wong L: Early olfactory experience, novelty, and choice of sexual partner by male rats. Physiol Behav 1996; 60:1361-1367.

-99 Sullivan RM, Wilson DA: Neural correlates of conditioned odor avoidance in infant rats. Behav Neurosci 1991;105:307-312.

100 Wilson DA, Sullivan RM, Leon M: Singleunit analysis of postnatal olfactory learning: modified olfactory bulb output response patterns to learned attractive odors. J Neurosci 1987;7:3154-3162.

101 Woo CC, Coopersmith R, Leon M: Localized changes in olfactory bulb morphology associated with early olfactory learning. J Comp Neurol 1987;263:113-125.

102 Yuan Q, Harley CW, Darby-King A, Neve RL, McLean JH: Early odor preference learning in the rat: bidirectional effects of cAMP response element-binding protein (CREB) and mutant CREB support a causal role for phosphorylated CREB. J Neurosci 2003;23:4760-4765.

Landers/Sullivan 
103 Zhang JJ, Okutani F, Inoue S, Kaba H: Ac- 117 Langdon PE, Harley CW, McLean JH: Intivation of the cyclic AMP response element-binding protein signaling pathway in the olfactory bulb is required for the acquisition of olfactory aversive learning in young rats. Neuroscience 2003;117:707713.

- 104 Sullivan RM, Leon M: Early olfactory learning induces an enhanced olfactory bulb response in young rats. Brain Res 1986;392:278-282.

105 Upton KJ, Sullivan RM: Defining age limits of the sensitive period for attachment learning in rat pups. Dev Psychobiol 2010;52: 453-464.

- 106 Yuan Q, Harley CW, McLean JH, Knopfel $\mathrm{T}$ : Optical imaging of odor preference memory in the rat olfactory bulb. J Neurophysiol 2002;87:3156-3159.

107 Coopersmith R, Leon M: Enhanced neural response by adult rats to odors experienced early in life. Brain Res 1986;371:400-403.

108 Sullivan RM, Wilson DA, Leon M: Norepinephrine and learning-induced plasticity in infant rat olfactory system. J Neurosci 1989;9:3998-4006.

109 Roth T, Wilson DA, Sullivan RM: Neurobehavioral development of infant learning and memory: designed for attachment; in Slater JR, Snowdon CT, Ropers TJ (eds): Advances in the Study of Behavior. San Diego, Elsevier Academic Press, 2004, vol 31, pp 103-123.

110 McLean JH, Harley CW, Darby-King A, Yuan Q: pCREB in the neonate rat olfactory bulb is selectively and transiently increased by odor preference-conditioned training. Learn Mem 1999;6:608-618.

-111 Shipley MT, Halloran FJ, de la Torre J: Surprisingly rich projection from locus coeruleus to the olfactory bulb in the rat. Brain Res 1985;329:294-299.

112 McLean JH, Shipley MT: Postnatal development of the noradrenergic projection from locus coeruleus to the olfactory bulb in the rat. J Comp Neurol 1991;304:467-477.

- 113 Sullivan RM, Zyzak DR, Skierkowski P, Wilson DA: The role of olfactory bulb norepinephrine in early olfactory learning. Brain Res Dev Brain Res 1992;70:279-282.

- 114 Sullivan RM, Stackenwalt G, Nasr F, Lemon C, Wilson DA: Association of an odor with activation of olfactory bulb noradrenergic beta-receptors or locus coeruleus stimulation is sufficient to produce learned approach responses to that odor in neonatal rats. Behav Neurosci 2000;114:957-962.

- 115 Okutani F, Kaba H, Takahashi S, Seto K: The biphasic effects of locus coeruleus noradrenergic activation on dendrodendritic inhibition in the rat olfactory bulb. Brain Res 1998;783:272-279.

-116 Sullivan RM, Wilson DA: The locus coeruleus, norepinephrine, and memory in newborns. Brain Res Bull 1994;35:467-472. creased beta adrenoceptor activation overcomes conditioned olfactory learning deficits induced by serotonin depletion. Brain Res Dev Brain Res 1997;102:291-293.

118 Rangel S, Leon M: Early odor preference training increases olfactory bulb norepinephrine. Brain Res Dev Brain Res 1995;85: 187-191.

-119 Bekinschtein P, Cammarota M, Izquierdo I, Medina JH: BDNF and memory formation and storage. Neuroscientist 2008;14:147156.

120 Tao X, Finkbeiner S, Arnold DB, Shaywitz AJ, Greenberg ME: $\mathrm{Ca}^{2+}$ influx regulates BDNF transcription by a CREB family transcription factor-dependent mechanism. Neuron 1998;20:709-726.

121 Carew TJ: Molecular enhancement of memory formation. Neuron 1996;16:5-8.

122 Carew TJ, Sutton MA: Molecular stepping stones in memory consolidation. Nat Neurosci 2001;4:769-771.

123 Rankin CH: Neuroscience. A bite to remember. Science 2002;296:1624-1625.

124 Nakamura S, Kimura F, Sakaguchi T: Postnatal development of electrical activity in the locus coeuruleus. J Neurophysiol 1987; 58:510-524.

125 Marshall KC, Christie MJ, Finlayson PG, Williams JT: Developmental aspects of the locus coeruleus-noradrenaline system. Prog Brain Res 1991;88:173-185.

126 Nakamura S, Sakaguchi T: Development and plasticity of the locus coeruleus: a review of recent physiological and pharmacological experimentation. Prog Neurobiol 1990;34:505-526.

127 Winzer-Serhan UH, Raymon HK, Broide RS, Chen Y, Leslie FM: Expression of alpha-2 adrenoceptors during rat brain development. 2. Alpha 2C messenger RNA expression and $\left[{ }^{3} \mathrm{H}\right]$ rauwolscine binding. Neuroscience 1997;76:261-272.

128 Ferry B, McGaugh JL: Role of amygdala norepinephrine in mediating stress hormone regulation of memory storage. Acta Pharmacol Sin 2000;21:481-493.

129 McGaugh JL: Make mild moments memorable: add a little arousal. Trends Cogn Sci 2006; 10:345-347.

130 Haberly LB: Parallel-distributed processing in olfactory cortex: new insights from morphological and physiological analysis of neuronal circuitry. Chem Senses 2001; 26:551-576.

131 Schwob JE, Price JL: The development of axonal connections in the central olfactory system of rats. J Comp Neurol 1984;223: 177-202.

132 Swanson LW, Petrovich GD: What is the amygdala? Trends Neurosci 1998;21:323331.

133 Wilson DA, Stevenson RJ: Olfactory perceptual learning: the critical role of memory in odor discrimination. Neurosci Biobehav Rev 2003;27:307-328.
134 Kadohisa M, Wilson DA: Separate encoding of identity and similarity of complex familiar odors in piriform cortex. Proc Natl Acad Sci USA 2006;103:15206-15211.

135 Simpson KL, Wang L, Kirifides MI, Lin RC, Waterhouse BD: Lateralization and functional organization of the locus coeruleus projection to the trigeminal somatosensory pathway in rat. J Comp Neurol 1997;385 135-147.

136 Levin BE, Craik RL, Hand PJ: The role of norepinephrine in adult rat somatosensory cortical metabolism and plasticity. Brain Res 1988;443:261-271.

137 Landers MS, Sullivan RM: Norepinephrine and associative conditioning in the neonatal rat somatosensory system. Brain Res Dev Brain Res 1999;114:261-264.

138 Harlow H, Harlow M: The affectional system; in Schrier A, Harlow H, Stollnitz F (eds): Behavior of Nonhuman Primates. New York, Academic Press, 1965, vol 2.

139 Maestripieri DM, Tomaszycki M, Carroll KA: Consistency and change in the behavior of rhesus macaque abusive mothers with successive infants. Dev Psychobiol 1999;34: 29-35.

140 Sanchez MM, Ladd CO, Plotskey PM: Early adverse experience as a developmental risk factor for later psychopathology: evidence from rodent and primate models. Dev Psychopathol 2001;13:419-449.

141 Suomi SJ: Early determinants of behaviour: evidence from primate studies. Br Med Bull 1997;53:170-184

142 Blozovski D, Cudennec A: Passive avoidance learning in the young rat. Dev Psychobiol 1980;13:513-518.

143 Collier A, Mast J, Meyer D, Jacobs C: Approach-avoidance conflict in preweanling rats: a developmental study. Anim Learn Behav 1979;7:514-520.

144 Goldman PS, Tobach E: Behaviour modification in infant rats. Anim Behav 1967;15: 559-562.

145 Stehouwer DJ, Campbell BA: Habituation of the forelimb-withdrawal response in neonatal rats. J Exp Psychol Anim Behay Process 1978;4:104-119.

146 Myslivecek J: Inhibitory learning and memory in newborn rats. Prog Neurobiol 1997; 53:399-430.

147 Barr GA: Ontogeny of nociception and antinociception. NIDA Res Monogr 1995;158: 172-201.

148 Moriceau S, Sullivan RM: Maternal presence serves as a switch between learning fear and attraction in infancy. Nat Neurosci 2006;9:1004-1006.

149 Emerich DF, Scalzo FM, Enters EK, Spear NE, Spear LP: Effects of 6-hydroxydopamine-induced catecholamine depletion on shock-precipitated wall climbing of infant rat pups. Dev Psychobiol 1985;18:215-227. 
150 Shair HN, Masmela JR, Brunelli SA, Hofer 166 Sevelinges Y, Gervais R, Messaoudi B, MA: Potentiation and inhibition of ultrasonic vocalization of rat pups: regulation by social cues. Dev Psychobiol 1997;30:195200.

151 Fitzgerald M: The development of nociceptive circuits. Nat Rev Neurosci 2005;6:507520.

152 Spear N: Processing Memories: Forgetting and Retention. Hillsdale, Erlbaum, 1978.

153 Moriceau S, Wilson DA, Levine S, Sullivan RM: Dual circuitry for odor-shock conditioning during infancy: corticosterone switches between fear and attraction via amygdala. J Neurosci 2006;26:6737-6748.

154 Collier AC, Meyer DR, Jacobs CE: Approach-avoidance conflict in preweanling rats: a developmental study. Anim Learn Behav 1979;7:514-520.

155 Davis M: Neurobiology of fear responses: the role of the amygdala. J Neuropsychiatry Clin Neurosci 1997;9:382-402.

156 Fanselow MS, Gale GD: The amygdala, fear, and memory. Ann NY Acad Sci 2003;985: 125-134.

157 Fanselow MS, LeDoux JE: Why we think plasticity underlying Pavlovian fear conditioning occurs in the basolateral amygdala. Neuron 1999;23:229-232.

158 Herzog C, Otto T: Odor-guided fear conditioning in rats. 2. Lesions of the anterior perirhinal cortex disrupt fear conditioned to the explicit conditioned stimulus but not to the training context. Behav Neurosci 1997;111:1265-1272.

159 Maren S: The amygdala, synaptic plasticity, and fear memory. Ann NY Acad Sci 2003; 985:106-113.

160 McGaugh JL, Roozendaal B, Cahill L: Modulation of memory storage by stress hormones and the amygdaloid complex; in Gazzaniga M (ed): Cognitive Neuroscience. Cambridge, MIT Press, 1999.

161 Pape HC, Stork O: Genes and mechanisms in the amygdala involved in the formation of fear memory. Ann NY Acad Sci 2003; 985:92-105.

162 Pare D, Quirk GJ, Ledoux JE: New vistas on amygdala networks in conditioned fear. J Neurophysiol 2004;92:1-9.

-163 Poulos AM, Li V, Sterlace SS, Tokushige F, Ponnusamy R, Fanselow MS: Persistence of fear memory across time requires the basolateral amygdala complex. Proc Natl Acad Sci USA 2009;106:11737-11741.

164 Sananes C, Campbell B: Role of the central nucleus of the amygdala in olfactory heart rate conditioning. Behav Neurosci 1989; 103:519-525.

165 Schettino LF, Otto T: Patterns of fos expression in the amygdala and ventral perirhinal cortex induced by training in an olfactory fear conditioning paradigm. Behav Neurosci 2001;115:1257-1272. Granjon L, Mouly AM: Olfactory fear conditioning induces field potential potentiation in rat olfactory cortex and amygdala. Learn Mem 2004;11:761-769.

167 Blair HT, Schafe GE, Bauer EP, Rodrigues SM, LeDoux JE: Synaptic plasticity in the lateral amygdala: a cellular hypothesis of fear conditioning. Learn Mem 2001;8:229242.

168 Sigurdsson T, Doyere V, Cain CK, LeDoux JE: Long-term potentiation in the amygdala: a cellular mechanism of fear learning and memory. Neuropharmacology 2007; 52:215-227.

169 Moriceau S, Roth TL, Okotoghaide T, Sullivan RM: Corticosterone controls the developmental emergence of fear and amygdala function to predator odors in infant rat pups. Int J Dev Neurosci 2004;22:415-422.

170 Wiedenmayer CP, Barr GA: Developmental changes in c-fos expression to an age-specific social stressor in infant rats. Behav Brain Res 2001;126:147-157.

171 Bayer SA: Quantitative ${ }^{3} \mathrm{H}$-thymidine radiographic analyses of neurogenesis in the rat amygdala. J Comp Neurol 1980;194: 845-875.

172 Berdel B, Morys J, Maciejewska B: Neuronal changes in the basolateral complex during development of the amygdala of the rat. Int J Dev Neurosci 1997;15:755-765.

173 Berdel B, Morys J: Expression of calbindinD28k and parvalbumin during development of rat's basolateral amygdaloid complex. Int J Dev Neurosci 2000;18:501-513.

174 Morys J, Berdel B, Jagalska-Majewska H, Luczynska A: The basolateral amygdaloid complex - Its development, morphology and functions. Folia Morphol (Warsz) 1999;58:29-46.

175 Bouwmeester H, Smits K, Van Ree JM: Neonatal development of projections to the basolateral amygdala from prefrontal and thalamic structures in rat. J Comp Neurol 2002;450:241-255.

176 Cunningham MG, Bhattacharyya S, Benes FM: Amygdalo-cortical sprouting continues into early adulthood: implications for the development of normal and abnormal function during adolescence. J Comp Neurol 2002;453:116-130. havior in infant rats: development of functional coupling between septal, hippocampal, and ventral tegmental regions. J Neurosci 1999;19:8646-8655.

178 Berdel B, Morys J: Expression of calbindinD28k and parvalbumin during development of rat's basolateral amygdaloid complex. Int J Dev Neurosci 2000;18:501-513.

179 Mizukawa K, Tseng IM, Otsuka N: Quantitative electron microscopic analysis of postnatal development of zinc-positive nerve endings in the rat amygdala using Timm's sulphide silver technique. Brain Res Dev Brain Res1989;50:197-203.
177 Nair H, Gonzalez-Lima F: Extinction of be-
80 Thompson JV, Sullivan RM, Wilson DA: Developmental emergence of fear learning corresponds with changes in amygdala synaptic plasticity. Brain Res 2008;1200: 58-65.

181 Helfer ME, Kempe RS, Krugman RD: The Battered Child. Chicago, University of Chicago Press, 1997.

182 Pollak SD: Experience-dependent affective learning and risk for psychopathology in children. Ann NY Acad Sci 2003;1008:102111.

183 Hoffmann H, Hunt P, Spear NE: Ontogenetic differences in the association of gustatory and tactile cues with lithium chloride and footshock. Behav Neural Biol 1990;53: 441-450.

184 Alleva E, Calamandrei G: Odor-aversion learning and retention span in neonatal mouse pups. Behav Neural Biol 1986;46: 348-357.

185 Coopersmith R, Lee S, Leon M: Olfactory bulb responses after odor aversion learning by young rats. Brain Res 1986;389:271-277.

186 Gruest N, Richer P, Hars B: Emergence of long-term memory for conditioned aversion in the rat fetus. Dev Psychobiol 2004; 44:189-198.

187 Hennessy JW, Smotherman WP, Levine S: Conditioned taste aversion and the pituitary-adrenal system. Behav Biol 1976;16: 413-424.

188 Smotherman WP, Hennessy JW, Levine S: Plasma corticosterone levels during recovery from $\mathrm{LiCl}$ produced taste aversions. Behav Biol 1976;16:401-412.

189 Hoffmann H, Molina JC, Kucharski D, Spear NE: Further examination of ontogenetic limitations on conditioned taste aversion. Dev Psychobiol 1987;20:455-463.

190 Hunt PS, Spear LP, Spear NE: An ontogenetic comparison of ethanol-mediated taste aversion learning and ethanol-induced hypothermia in preweanling rats. Behav Neurosci 1991;105:971-983.

191 Hunt PS, Molina JC, Rajachandran L, Spear LP, Spear NE: Chronic administration of alcohol in the developing rat: expression of functional tolerance and alcohol olfactory aversions. Behav Neural Biol 1993;59:8799.

192 Miller JS, Molina JC, Spear NE: Ontogenetic differences in the expression of odoraversion learning in 4- and 8-day-old rats. Dev Psychobiol 1990;23:319-330.

193 Molina JC, Hoffmann H, Spear NE: Conditioning of aversion to alcohol orosensory cues in 5- and 10-day rats: subsequent reduction in alcohol ingestion. Dev Psychobiol 1986;19:175-183.

194 Richardson R, McNally GP: Effects of an odor paired with illness on startle, freezing, and analgesia in rats. Physiol Behav 2003; 78:213-219. 
195 Rudy JW, Cheatle MD: Odor-aversion learning by rats following $\mathrm{LiCl}$ exposure: ontogenetic influences. Dev Psychobiol 1983;16:13-22.

196 Smotherman WP: Odor aversion learning by the rat fetus. Physiol Behav 1982;29:769771.

197 Smotherman WP, Robinson SR: The rat fetus in its environment: behavioral adjustments to novel, familiar, aversive, and conditioned stimuli presented in utero. Behav Neurosci 1985;99:521-530.

-198 Smotherman WP, Robinson SR: Rat fetuses respond to chemical stimuli in gas phase. Physiol Behav 1990;47:863-868.

199 Stickrod G, Kimble DP, Smotherman WP: In utero taste/odor aversion conditioning in the rat. Physiol Behav 1982;28:5-7.

200 Shionoya K, Moriceau S, Lunday L, Miner C, Roth TL, Sullivan RM: Development switch in neural circuitry underlying odormalaise learning. Learn Mem 2006;13:801808.

201 Raineki C, Shionoya K, Sander K, Sullivan RM: Ontogeny of odor-LiCl vs odor-shock learning: similar behaviors but divergent ages of amygdala functional emergence. Learn Mem 2009;16:114-212.

202 Abate P, Spear NE, Molina JC: Fetal and infantile alcohol-mediated associative learning in the rat. Alcohol Clin Exp Res 2001;25: 989-998.

203 Spear NE, Rudy JW: Tests of the ontogeny of learning and memory: issues, methods, and results; in Shair HN, Barr GA (eds): Developmental Psychobiology: New Methods and Changing Concepts. New York, Oxford University Press, 1991, pp 84-113.

-204 Bermudez-Rattoni F, Grijalva CV, Kiefer SW, Garcia J: Flavor-illness aversions: the role of the amygdala in the acquisition of taste-potentiated odor aversions. Physiol Behav 1986;38:503-508.

-205 Touzani K, Sclafani A: Critical role of amygdala in flavor but not taste preference learning in rats. Eur J Neurosci 2005;22: 1767-1774.

-206 Gubernick DJ, Alberts JR: A specialization of taste aversion learning during suckling and its weaning-associated transformation. Dev Psychobiol 1984;17:613-628.

207 Martin LT, Alberts JR: Taste aversions to mother's milk: the age-related role of nursing in acquisition and expression of a learned association. J Comp Physiol Psychol 1979;93:430-445.

208 Melcer T, Alberts JR, Gubernick DJ: Early weaning does not accelerate the expression of nursing-related taste aversions. Dev Psychobiol 1985;18:375-381.

-209 Walker C, Sapolsky R, Meaney M, Vale W, Rivier C: Increased pituitary sensitivity to glucocorticoid feedback during the stress nonresponsive period in the neonatal rat. Endocrinology 1986;119:1816-1821.
210 Henning SJ: Plasma concentrations of total and free corticosterone during development in the rat. Am J Physiol 1978;235:451456.

211 Grino M, Paulmyer-Lacroix O, Faudon M, Renard M, Anglade G: Blockade of alpha 2-adrenoceptors stimulates basal and stress-induced adrenocorticotropin secretion in the developing rat through a central mechanism independent from corticotropin-releasing factor and arginine vasopressin. Endocrinology 1994;135:2549-2557.

212 Levine S: Plasma-free corticosteroid response to electric shock in rats stimulated in infancy. Science 1962;135:795-796.

213 Rosenfeld P, Suchecki D, Levine S: Multifactorial regulation of the hypothalamic pituitary-adrenal axis during development. Neurosci Biobehav Rev 1992;16:553-568.

214 Guillet R, Michaelson SM: Corticotropin responsiveness in the neonatal rat. Neuroendocrinology 1978;27:119-125.

215 Levine S: Maternal and environmental influences on the adrenocortical response to stress in weanling rats. Science $1967 ; 156$ : 258-260.

216 Butte JC, Kakihana R, Farnham ML, Noble EP: The relationship between brain and plasma corticosterone stress response in developing rats. Endocrinology 1973;92: 1775-1779.

217 Guillet R, Saffran M, Michaelson SM: Pituitary-adrenal response in neonatal rats. Endocrinology 1980;106:991-994.

218 Dalman M: Editorial: moments in time the neonatal rat hypothalamo-pituitaryadrenal axis. Endocrinology 2000;141; 1590-1592.

219 VanOers H, Kloet ED, Whelan T, Levine S: Maternal deprivation effect on the infant's neural stress markers is reversed by tactile stimulation and feeding but not by suppressing corticosterone. Neuroscience 1998;18:10171-10179.

220 Stanton ME, Wallstrom J, Levine S: Maternal contact inhibits pituitary-adrenal stress responses in preweanling rats. Dev Psychobiol 1987;20:131-145.

221 Stanton M, Levine S: Inhibition of infant glucocorticoid stress response: specific role of maternal cues. Dev Psychobiol 1990;23: 411-426.

222 Suchecki D, Rosenfeld P, Levine S: Maternal regulation of the hypothalamic-pituitary-adrenal axis in the infant rat: the roles of feeding and stroking. Brain Res Dev Brain Res 1993;75:185-192.

223 Sapolsky RM, Meaney MJ: Maturation of the adrenocortical stress response: neuroendocrine control mechanisms and the stress hyporesponsive period. Brain Res 1986;396:64-76.

224 Erkine MS, Geller E, Yuwiler A: Effects of neonatal hydrocortisone treatment on pituitary and adrenocortical responses to stress in young rats. Neuroendocrinology 1979;29:191-199.
225 Bohn MC: Granule cell genesis in the hippocampus of rats treated neonatally with hydrocortisone. Neuroscience 1980;5: 2003-2012.

226 Roozendaal B, Quirarte GL, McGaugh JL: Glucocorticoids interact with the basolateral amygdala beta-adrenoceptor - cAMP/ cAMP/PKA system in influencing memory consolidation. Eur J Neurosci 2002; 15:553560.

227 Hui GK, Figueroa IR, Poytress BS, Roozendaal B, McGaugh JL, Weinberger NM: Memory enhancement of classical fear conditioning by post-training injections of corticosterone in rats. Neurobiol Learn Mem 2004;81:67-74.

228 Pugh CR, Tremblay D, Fleshner M, Rudy JW: A selective role for corticosterone in contextual-fear conditioning. Behav Neurosci 1997;111:503-511.

229 Thompson BL, Erickson K, Schulkin J, Rosen JB: Corticosterone facilitates retention of contextually conditioned fear and increases CRH mRNA expression in the amygdala. Behav Brain Res 2004;149:209215.

230 Roozendaal B, Carmi O, McGaugh JL: Adrenocortical suppression blocks the memory-enhancing effects of amphetamine and epinephrine. Proc Natl Acad Sci USA 1996; 93:1429-1433.

231 Takahashi LK: Organizing action of corticosterone on the development of behavioral inhibition in the preweanling rat. Brain Res Dev Brain Res 1994;81:121-127.

232 Pacák K, Palkovits M, Kvetnanský R, Yadid G, Kopin IJ, Goldstein DS: Effects of various stressors on in vivo norepinephrine release in the hypothalamic paraventricular nucleus and on the pituitary-adrenocortical axis. Ann NY Acad Sci 1995;771:115130.

233 Shanks N, Windle RJ, Perks P, Wood S, Ingram CD, Lightman SL: The hypothalamicpituitary-adrenal axis response to endotoxin is attenuated during lactation. J Neuroendocrinol 1999;11:857-865.

234 Toufexis DJ, Walker CD: Noradrenergic facilitation of the adrenocorticotropin response to stress is absent during lactation in the rat. Brain Res 1996;737:71-77.

235 Deschamps S, Woodside B, Walker CD: Pups presence eliminates the stress hyporesponsiveness of early lactating females to a psychological stress representing a threat to the pups. J Neuroendocrinol 2003;15:486497.

236 Walker CD, Deschamps S, Proulx K, Tu M, Salzman C, Woodside B, Lupien S, GalloPayet N, Richard D: Mother to infant or infant to mother? Reciprocal regulation of responsiveness to stress in rodents and the implications for humans. J Psychiatry Neurosci 2004;29:364-382. 
237 Sevelinges Y, Mouly MA, Moriceau S, 249 Ladd CO, Huot RL, Thrivikraman KV, Raineki C, Forest C, Sullivan RM: Adult depression-like behavior and amygdala dysfunction rescued by odor previously paired with shock in infancy. Dev Cogn Neurosci 2011;1:77-87.

-238 Sevelinges Y, Moriceau S, Holman P, Miner C, Muzny K, Gervais R, Mouly A, Sullivan R: Enduring effects of infant memories: infant odor-shock conditioning attenuates amygdala activity and adult fear conditioning. Biol Psychiatry 2007;62:1070-1079.

239 Rosenzweig MR, Bennett EL, Diamond MC, Wu SY, Slagle RW, Saffran E: Influences of environmental complexity and visual stimulation on development of occipital cortex in rat. Brain Res 1969;14:427445.

240 Schore AN: The effects of early relational trauma on right brain development, affect regulation, and infant mental health. Infant Mental Health J 2001;22:201-269.

241 Liu D, Caldji C, Sharma S, Plotsky P, Meaney M: Influence of neonatal rearing conditions on stress-induced adrenocorticotropin responses and norepinepherine release in the hypothalamic paraventricular nucleus. J Endocrinol 2000;12:5-12.

242 Meaney MJ: Maternal care, gene expression, and the transmission of individual differences in stress reactivity across generations. Ann Rev Neurosci 2001;24:11611192.

243 Andersen SL, Lyss PJ, Dumount NL, Teicher $\mathrm{MH}$ : Enduring neurochemical effects of early maternal separation on limbic structures. Ann NY Acad Sci 1999;877: 756-759.

-244 Higley JD, Hasert MF, Suomi SJ, Linnoila M: Nonhuman primate model of alcohol abuse: Effects of early experience, personality, and stress on alcohol consumption. Proc Natl Acad Sci USA 1991;88:7261-7265.

245 Plotsky PM, Meaney MJ: Early postnatal experience alters hypothalamic corticotropin-releasing factor (CRF) mRNA, median eminence CRF content and stress-induced release in adult rats. Brain Res Mol Brain Res 1993;18:195-200.

246 Avishai-Eliner S, Gilles EE, Eghbal-Ahmadi M, Bar-El Y, Baram TZ: Altered regulation of gene and protein expression of hypothalamic-pituitary-adrenal axis components in an immature rat model of chronic stress. J Neuroendocrinol 2001;15:114-119.

247 Suomi SJ: Gene-environment interactions and the neurobiology of social conflict. Ann NY Acad Sci 2003;1008:132-139.

248 Hall FS, Wilkinson LS, Humby T, Robbins TW: Maternal deprivation of neonatal rats produces enduring changes in dopamine function. Synapse 1999;32:37-43. Nemeroff CB, Meaney MJ, Plotsky PM: Long-term behavioral and neuroendocrine adaptations to adverse early experience. Prog Brain Res 2000;122:81-103.

250 Kaffman A, Meaney MJ: Neurodevelopmental sequelae of postnatal maternal care in rodents: clinical and research implications of molecular insights. J Child Psychol Psychiatry 2007;48:224-244.

251 Caldji C, Diorio J, Meaney MJ: Variations in maternal care alter GABA(A) receptor subunit expression in brain regions associated with fear. Neuropsychopharmacology 2003;28:1950-1959.

252 Hofer MA, Shair HN: Independence of ultrasonic vocalization and thermogenic responses in infant rats. Behav Neurosci 1991; 105:41-48.

253 Hofer MA: Hidden regulatory processes in early social relationships; in Bateson PP, Klopfer PK (eds): Perspectives in Ethology: Social Relationships. New York, Plenum, 1978, pp 147-157.

254 Hofer MA, Shair HN: Ultrasonic vocalization during social interaction and isolation in 2-week-old rats. Dev Psychobiol 1978;11: 495-504.

255 Nelson CA, Zeanah CH, Fox NA, Marshall PJ, Smyke AT, Guthrie D: Cognitive recovery in socially deprived young children: the Bucharest Early Intervention Project. Science 2007:318:1937-1940.

256 Smyke AT, Zeanah CH Jr, Fox NA, Nelson CA: A new model of foster care for young children: the Bucharest early intervention project. Child Adolesc Psychiatr Clin N Am 2009;18:721-734.

257 Windsor J, Benigno JP, Wing CA, Carroll PJ, Koga SF, Nelson CA, Fox NA, Zeanah $\mathrm{CH}$ : Effect of foster care on young children's language learning. Child Dev 2011; 82:1040-1046.

258 McLaughlin KA, Zeanah CH, Fox NA, Nelson CA: Attachment security as a mechanism linking foster care placement to improved mental health outcomes in previously institutionalized children. J Child Psychol Psychiatry 2012;53:46-55.

259 Fox NA, Almas AN, Degnan KA, Nelson $\mathrm{CA}$, Zeanah $\mathrm{CH}$ : The effects of severe psychosocial deprivation and foster care intervention on cognitive development at 8 years of age: findings from the Bucharest Early Intervention Project. J Child Psychol Psychiatry 2011;52:919-928.

260 McLaughlin KA, Fox NA, Zeanah CH, Nelson CA: Adverse rearing environments and neural development in children: the development of frontal electroencephalogram asymmetry. Biol Psychiatry 2011;70:10081015.
61 Zeanah CH, Keyes A, Settles L: Attachment relationship experiences and childhood psychopathology. Ann NY Acad Sci 2003; 1008:22-30

262 Oberlander TF, Weinberg J, Papsdorf M, Grunau R, Misri S, Devlin D: Prenatal exposure to maternal depression, neonatal methylation of human glucocorticoid receptor gene (NR3C1) and infant cortisol stress responses. Epigenetics 2008;3:1-9.

263 Bremner JD: Long-term effects of childhood abuse on brain and neurobiology. Child Adolesc Psychiatr Clin N Am 2003; 12:271-292.

264 Kaufman J, Plotsky PM, Nemeroff CB, Charney DS: Effects of early adverse experiences on brain structure and function: clinical implications. Biol Psychiatry 2000;48: 778-790.

265 Pollak SD, Nelson CA, Schlaak M, Roeber B, Wewerka SS, Wiik KL, Frenn K, Loman MM, Gunnar MR: Neurodevelopmental effects of early deprivation in post-institutionalized children. Child Dev 2010;81: 224-236.

266 Pryce CR: Postnatal ontogeny of expression of the corticosteroid receptor genes in mammalian brains: inter-species and intra-species differences. Brain Res Rev 2008; 57:596-605.

267 Shah A, Oxley G, Lovic V, Fleming AS: Effects of preweaning exposure to novel maternal odors on maternal responsiveness and selectivity in adulthood. Dev Psychobiol 2002;41:187-196.

268 Gunnar M, Quevedo K: The neurobiology of stress and development. Ann Rev Psychol 2007;58:145-173.

269 Teicher MH, Andersen SL, Polcari A, Anderson CM, Navalta CP, Kim DM: The neurobiological consequences of early stress and childhood maltreatment. Neurosci Biobehav Rev 2003;27:33-44.

270 Nemeroff CB: Neurobiological consequences of childhood trauma. J Clin Psychiatry 2004;1:18-28.

271 Lupien SJ, Parent S, Evans AC, Tremblay RE, Zelazo PD, Corbo V, Pruessner JC, Séguin JR: Larger amygdala but no change in hippocampal volume in 10-year-old children exposed to maternal depressive symptomatology since birth. Proc Natl Acad Sci USA 2011;108:14324-14329.

272 Harlow HF: Love in infant monkeys. Sci Am 1959;200:68-74.

273 Hinde RA, Davies LM: Changes in motherinfant relationship after separation in rhesus monkeys. Nature 1972;239:41-42.

274 Hinde RA, White LE: Dynamics of a relationship: rhesus mother-infant ventro-ventral contact. J Comp Physiol Psychol 1974; 86:8-23. 